\title{
Otomasi Layanan Cetak Pada Sistem Cloud Printing menggunakan CUPS
}

\author{
Rachman S. Marjianto ${ }^{1}$, Nanda R. Wirowicaksono² \\ Address: Fakultas Vokasi Universitas Airlangga, D3 Sistem Informasi, Indonesia \\ Email: rachmanmarjianto@gmail.com ${ }^{1}$,ridho.wiro@gmail.com²
}

\begin{abstract}
Abstrak
Mencetak dokumen telah menjadi sebuah kebutuhan dari seluruh individu atau organisasi, terutama civitas akademik. Survey yang dilakukan kepada 100 mahasiswa sebagai responden untuk melihat kebutuhan layanan cetak di dalam lingkungan Fakultas Vokasi Universitas Airlangga menunjukan tingginya kebutuhan layanan cetak dan hal tersebut belum terpenuhi. Model Kano digunakan untuk melakukan survey kebutuhan fitur layanan cetak dan hasilnya menunjukan bahwa layanan cetak yang ditawarkan secara online dapat memberikan dampak positif bagi layanan cetak tersebut. Organisasi yang akan memberikan layanan cetak ini adalah himpunan mahasiswa dimana ketersediaan waktunya terbatas karena tingginya jam perkuliahan. Oleh sebab itu diperlukan sebuah sistem layanan cetak yang bekerja secara otonom. Tiga buah background proses dikembangkan untuk menjalankan sistem layanan cetak otomatis dimana komunikasi dengan printer-printer yang tersedia menggunakan CUPS.
\end{abstract}

\section{Keywords - CUPS, Cloud Printing System, Web Based Printing System}

\section{Latar Belakang}

Mencetak sebuah dokumen adalah sebuah kebutuhan dari seluruh inidividu atau organisasi untuk memenuhi kebutuhan dokumentasi data pada media kertas. Printer menjadi sebuah kebutuhan dasar pada sebagian besar proses bisnis yang harus dipenuhi. Dengan perkembangan teknologi, sebuah printer pada umumnya akan dibagikan untuk digunakan secara bersama. Kendala umum yang terjadi adalah driver printer harus terpasang pada setiap komputer yang akan menggunakannya, jika sebuah perangkat print server digunakan. Jika printer secara langsung dibagikan melalui jaringan, konfigurasi pada sisi client diperlukan dimana hanya sebagian pengguna yang mampu melakukannya.

Di lingkungan civitas akademik, mencetak dokumen merupakan aktifitas yang dilakukan dengan frekuensi yang tinggi. Oleh sebab itu banyak penyedia jasa cetak yang tersebar disekitar lingkungan universitas untuk memenuhi kebutuhan ini. Pada penelitian ini dikembangkan sebuah Sistem Cloud Printing (SCP) dengan mengambil studi kasus untuk menyelesaikan permasalahan layanan cetak dokumen di kalangan Mahasiswa di Fakultas Vokasi Universitas Airlangga. Observasi pada penyedia jasa cetak disekitar Fakultas dan survey pada 100 Mahasiswa dilakukan untuk mengumpulkan data guna mendukung perlunya penelitian ini dilakukan. Pada perancangan sistem, keterlibatan calon pengguna dapat membantu untuk menentukan fitur-fitur yang perlu dimiliki oleh sistem. Survey yang dilakukan untuk memodelkan kebutuhan calon pengguna disusun menggunakan model kano [1].

Wu et al. [2], Levine et al [3], dan Tanaka [4] adalah tiga penilitian pendahulu dibidang web based cloud printing yang dipatenkan oleh perusahaan Xerox dan Canon. Perangkat lunak berbayar yang menawarkan fitur cloud printing, seperti Papercut [5] dan ThinPrint Cloud Services [6], adalah contoh produk-produk yang sudah ada. Harga lisensi untuk menggunakan perangkat lunak tersebut bergantung pada fitur yang akan digunakan dan jumlah pengguna. Dukungan layanan untuk update kedua produk dibatasi hanya 1 tahun. Pada penelitian ini dikembangkan sebuah sistem yang juga memberikan layanan cetak menggunakan media web.

Pada penelitian yang dilakukan, SCP dirancang untuk dioperasikan oleh mahasiswa sebagai penyedia jasa dan juga akan digunakan oleh mahasiswa sebagai pengguna layanan tersebut. Ketersediaan layanan cetak harus terus tersedia dimana hal tersebut berlawanan dengan ketersediaan waktu mahasiswa sebagai operator sistem. Berdasarkan permasalahan tersebut, SCP dirancang

Program Studi Teknik Informatika

Universitas Prima Indonesia (UNPRI) Medan 
untuk dapat berjalan secara otonom dan akan memberikan notifikasi untuk beberapa kondisi yang terjadi. Untuk menggunakan layanan cetak pengguna dapat mengunggah file yang ingin dicetak melalui layanan web pengguna. SCP terdiri dari dua Modul, yaitu Modul Sistem Informasi Layanan Cetak berbasis web dan Modul otomasi cetak dokumen yang berfungsi untuk manajemen printer. Modul kedua SCP terdiri dari layanan web yang hanya dapat diakses oleh administrator sistem untuk melakukan manajemen printer dan tiga background proses yang bertugas untuk mengirimkan sebuah print job ke printer dan memeriksa status printer dan print job secara berkala.

Untuk memenuhi kebutuhan sistem pada modul kedua, Common Unix Printing System (CUPS) digunakan. CUPS adalah perangkat lunak yang digunakan oleh sistem operasi Linux untuk layanan cetak. CUPS memiliki kumpulan driver dari sebagian besar printer yang ada di pasar. CUPS mempunyai layanan Spooling Printer dan penjadwalan cetak, selain itu CUPS juga menyediakan command line interface (CLI) untuk mengeksekusi perintah.

Antrian print job menggunakan metode First In First Out (FIFO) dan pembagian print job ke printer-printer yang terkoneksi menggunakan metode load balancing. Load balancing adalah sebuah konsep yang bertujuan untuk membagi beban pada infrastruktur Teknologi Informasi secara seimbang [7]. Pembagian yang seimbang pada kasus ini adalah pembagian antrian print Job ke beberapa printer. Sebuah print job dalam antrian akan segera dilayani, jika terdapat sebuah printer yang berstatus idle.

\section{Metode}

\subsection{Kano Model}

Kano model adalah sebuah model yang digunakan untuk mengukur persepsi pengguna dan dampak terhadap kualitas produk berdasarkan kepuasan yang mereka rasakan [8]. Untuk mendapatkan persepsi pelanggan terhadap sebuah produk, dua pertanyaan tentang tersedianya dan tidak tersedianya sebuah fitur pada produk tersebut diberikan kepada responden. Persepsi pelanggan terhadap fitur berdasarkan jawaban questioner dapat diklasifikasikan kedalam 5 kategori:

\section{1) Performance}

Kepuasan pelanggan berbanding linear terhadap keberadaan fitur. Keberadaan fitur akan meningkatkan kepuasan pelanggan dan jika fitur tersebut tidak dipenuhi akan mengakibatkan ketidakpuasan.

2) Must-be
Fitur yang masuk dalam kategori ini pada umumnya adalah fitur dasar yang harus ada. Jika fitur ini tidak ada pada sebuah produk, maka produk akan dikatakan buruk.

\section{3) Attractive}

Fitur pada kategori ini pada umumnya adalah fitur baru. Keberadaan fitur ini berdampak sangat positif terhadap prespektif pelanggan terhadap sebuah produk.

4) Indiferent

Ada atau tidaknya fitur tidak akan berpengaruh apa pun terhadap prespektif pelanggan pada sebuah produk.

5) Reverse

Keberadaan fitur akan menghasilkan prespektif negatif pada sebuah produk.

Penelitian [9] menambahkan sebuah kategori "Questionable" untuk melihat konsistensi jawaban reponden. Jawaban dari responden yang masuk dalam kategori ini dinyatakan tidak valid. Kategori ini digunakan untuk memfilter pengisian lembar survey oleh responden yang dilakukan secara acak, akan tetapi formulasi pertanyaan yang kurang jelas bisa menjadi salah satu penyebabnya.

\subsection{Load Balancing}

Load Balancing adalah sebuah konsep yang bertujuan untuk membagi rata beban kerja pada infrastruktur Teknologi Informasi secara seimbang [7]. Sebuah beban pada sistem ini adalah sebuah print job, sehingga load balancing yang diterapkan pada sistem ini adalah mendistribusikan print job kepada printer-printer yang beroperasi secara merata.

Penggunaan metode load balancing bertujuan untuk menghindari pemberian beban yang terpusat pada satu printer. Hal ini bertujuan untuk meningkatkan performa layanan cetak yang dapat dilayani oleh SCP. CUPS sebenarnya telah dilengkapi dengan fitur antrian print job, akan tetapi fitur antrian ini adalah antrian print job yang diberikan untuk masing-masing printer. Sehingga sebuah print job yang berada pada sebuah antrian dari sebuah printer tertentu akan terhenti atau terhambat untuk dilayani, jika terdapat masalah pada printer tersebut. Oleh sebab itu dikembangkan sebuah sistem antrian pada SCP yang hanya memberikan satu print job pada sebuah printer. Satu print job tersebut akan diberikan pada sebuah printer yang memiliki status idle dengan spesifikasi cetak yang sesuai. Print job lainnya akan disimpan dalam antrian SCP, jika seluruh printer memiliki status busy atau sedang melakukan proses cetak. Dengan demikian print job dapat dibagikan secara merata 
kepada seluruh printer dan dapat menghindari hambatan pada proses cetak dari beberapa print job, jika terdapat satu atau beberapa printer yang bermasalah.

\subsection{Mendefinisikan Kebutuhan Sistem}

Penelitian ini tidak hanya bertujuan membangun sebuah sistem untuk memenuhi kebutuhan layanan cetak, tetapi juga membangun sebuah sistem layanan cetak dengan fitur lebih dibandingkan dengan layanan cetak pada umumnya.

Untuk mendapatkan data terkait kebutuhan sistem dilakukan dengan cara observasi pada tempat penyedia jasa disekitar lingkungan Fakultas Vokasi Universitas Airlangga, wawancara secara langsung kepada pengelola layanan cetak dan mahasiswa sebagai pengguna layanan dan dilakukan survey menggunakan kuisioner yang diberikan kepada mahasiswa untuk menentukan fiturfitur yang diharapkan. Kano model dalam hal ini digunakan untuk menyusun pertanyaan pada kuisioner tersebut.

\subsection{Perancangan Sistem}

Hasil identifikasi kebutuhan menghasilkan fitur-fitur yang diperlukan oleh SCP dan proses bisnis yang harus dipenuhi oleh SCP yang akan dimodelkan dengan menggunakan flowchart dan sequence diagram. Dengan flowchart dapat digambarkan alur kerja dari sebuah proses bisnis dan dengan sequence diagram dapat dijelaskan bagaimana modul-modul didalam sitem berinteraksi untuk menjalankan sebuah proses bisnis.

\section{Hasil}

\subsection{Hasil Survey}

SCP yang dikembangkan pada penelitian ini mengambil studi kasus di lingkungan Fakultas Vokasi Universitas Airlangga. Survey dilakukan kepada 100 Mahasiswa Fakultas Vokasi Universitas Airlangga. Hasil survey menunjukan bahwa $72 \%$ responden setuju bahwa didalam lingkungan fakultas belum tersedia layanan jasa cetak dan $96 \%$ responden merasakan perlu adanya layanan cetak didalam lingkungan fakultas. 59\% responden menggunakan jasa cetak sebanyak 3-6 kali dalam seminggu dan $31 \%$ responden menggunakan jasa cetak dibawah 3 kali dalam seminggu. 92\% responden menyatakan jenis dokumen yang dicetak adalah tugas perkuliahan. Dari hasil survey dapat ditarik kesimpulan bahwa layanan jasa cetak didalam lingkungan Fakultas Vokasi memiliki potensi yang baik sebagai unit usaha dilingkungan Fakultas. SCP akan digunakan oleh unit usaha milik himpunan mahasiswa.

\subsection{Analisa Kebutuhan Fitur Dengan Kano Model}

Survey yang dilakukan menggunakan model ini bertujuan untuk melihat perspektif calon pengguna terhadap keberadaan sembilan fitur seperti yang terlihat pada tabel 1. Tiga fitur yang terkategori "Attractive" adalah layanan cetak online, bebas virus dan notifikasi cetak selesai. Keberadaan ketiga fitur ini memiliki dampak

yang sangat positif terhadap layanan cetak SCP. Hal tersebut menjadi sangat menarik untuk calon pengguna, dalam hal ini adalah mahasiswa Fakultas Vokasi

Universitas Airlangga, karena ketiga fitur tersebut merupakan solusi terhadap permasalahan yang sering muncul pada layanan cetak dokumen yang ada di sekitar

fakultas vokasi. Antrian yang panjang, jarak penyedia layanan dari fakultas vokasi dan flashdisk yang terserang virus setelah digunakan untuk mentransfer data ke

komputer milik penyedia jasa layanan merupakan permasalahan yang sering dikeluhkan. Layanan secara online dan tetap dapat beraktifitas selama proses cetak merupakan fitur baru yang belum tersedia hingga saat ini.

Untuk dapat menggunakan layanan cetak SCP,

pengguna diwajibkan untuk melakukan registrasi dan memiliki saldo. Kedua hal tersebut terkategori sebagai

"Indifferent". Hal ini dapat diinterpretasi bahwa calon

pengguna merasa tidak keberatan untuk memenuhi kedua kewajiban tersebut untuk menggunakan layanan SCP.

Tabel 1 Hasil survey menggunakan model kano

\begin{tabular}{|l|c|c|c|c|c|c|c|c|}
\hline \multicolumn{1}{|c|}{ Fitur } & M & P & A & I & R & Q & $\begin{array}{c}\text { To- } \\
\text { tal }\end{array}$ & Kat \\
\hline $\begin{array}{l}\text { Layanan } \\
\text { Cetak Online }\end{array}$ & 2 & 10 & 41 & 23 & 2 & 26 & 104 & A \\
\hline Bebas Virus & 10 & 24 & 37 & 28 & 1 & 4 & 104 & A \\
\hline $\begin{array}{l}\text { Kewajiban } \\
\text { Registrasi }\end{array}$ & 2 & 3 & 31 & 42 & 6 & 20 & 104 & I \\
\hline $\begin{array}{l}\text { Top Up Saldo } \\
\text { Sortir Hasil } \\
\text { Cetak }\end{array}$ & 3 & 1 & 11 & 50 & 17 & 22 & 104 & I \\
\hline $\begin{array}{l}\text { Rincian } \\
\text { Penggunaan } \\
\text { Saldo }\end{array}$ & 3 & 9 & 16 & 58 & 4 & 14 & 104 & I \\
\hline $\begin{array}{l}\text { Pisah Warna } \\
\text { dan H/P }\end{array}$ & 6 & 2 & 12 & 45 & 7 & 32 & 104 & I \\
\hline $\begin{array}{l}\text { Notifikasi } \\
\text { Cetak Selesai }\end{array}$ & 5 & 9 & 40 & 31 & 5 & 14 & 104 & $\mathrm{~A}$ \\
\hline $\begin{array}{l}\text { Prioritas } \\
\text { Cetak }\end{array}$ & 5 & 4 & 7 & 53 & 4 & 31 & 104 & I \\
\hline
\end{tabular}

Fitur sortir hasil cetak bertujuan untuk memisahkan hasil cetak dari print job yang berbeda. Karena SCP beroperasi secara otonom, hasil cetak dari beberapa print job akan sulit untuk dibedakan jika para pengguna 
tersebut tidak secara langsung mengambil hasil cetaknya. Hasil cetak beberapa print job tersebut akan tertumpuk satu dengan yang lainnya. Keberadaan fitur ini bermaksud untuk memberikan tanda pemisah hasil cetak dari print job yang berbeda. Keberadaan fitur ini pada SCP tidak memberi dampak apapun kepada calon pengguna, terlihat dari hasil survey pada fitur ini terkategori "Indifferent".Rincian penggunaan saldo, pemberian informasi detail printer yang mampu mencetak warna atau hanya hitam putih dan pemberian prioritas cetak cepat juga terkategori "Indifferent". Oleh sebab itu, SCP tidak perlu dilengkapi dengan keempat fitur ini.

\subsection{Implementasi Sistem}

Berdasarkan hasil analisa kebutuhan pada sub bab 3.2, ketersediaan layanan cetak secara online dan notifikasi cetak selesai terkategori "Attractive", untuk memenuhi hal tersebut SCP harus mampu bekerja secara otonom karena mahasiswa sebagai operator memiliki ketersediaan waktu yang terbatas. Oleh sebab itu implementasi sistem agar bekerja secara otonom menjadi fokus pembahasan pada bab ini.

Implementasi SCP secara fisik tergambar pada gambar 1, dimana SCP akan terinstall pada sebuah Server. Pada server tersebut berjalan tiga services, yaitu web server, SQL Server dan CUPS. Printer-printer yang akan digunakan untuk melayani layanan cetak terkoneksi secara langsung ke Server menggunakan koneksi kabel USB.

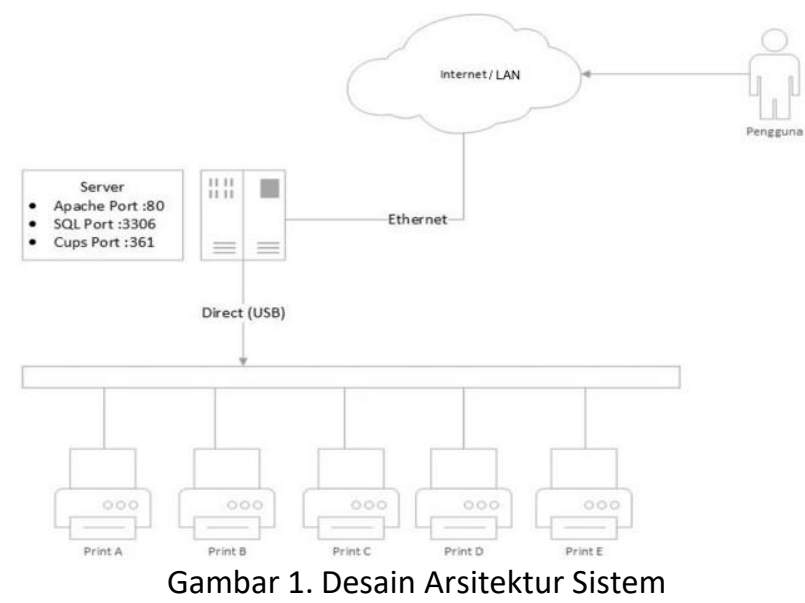

SCP terbagi menjadi dua modul, yaitu Modul Sistem Informasi Layanan Cetak atau pada fokus pembahasan ini modul tersebit bekerja sebagai sistem billing dan Modul otomasi cetak. Modul otomasi cetak terdiri dari layanan web yang berfungsi untuk manajemen printer dan background proses yang bertugas melakukan otomasi cetak itu sendiri. Interaksi antara modul sistem billing dan backgroud proses otomasi cetak untuk menyelesaikan sebuah print job terlihat pada gambar 2. Background proses otomasi cetak menggunakan perintah-perintah yang tersedia pada CUPS untuk mengirimkan perintah sebuah print job kepada printer.

CUPS dilengkapi dengan sebuah sistem antrian print job, setiap print job yang dikirim ke CUPS dilengkapi dengan printer tujuan yang akan mencetak print job tersebut. SCP hanya akan mengirimkan satu print job untuk masing-masing printer, print job lainnya berada pada sistem antrian SCP. Hal ini dilakukan untuk menghindari terhentinya layanan cetak pada antrian print job untuk printer tertentu yang disebabkan karena printer teresbut mengalami masalah. Beberapa kejadian yang merupakan sebuah masalah pada printer diantaranya adalah paper jam, out of paper atau printer dalam kondisi mati dengan sendirinya. SCP menyimpan antrian print job dan status printer-printer yang terinstall pada server didalam database. Oleh sebab itu diperlukan tiga buah background proses yang berfungsi untuk memeriksaan dan memperbarui status printer (pull printer status), background proses yang berfungsi untuk memeriksa dan memperbarui status print job (pull print job status) dan background proses yang berfungsi untuk mengirim perintah cetak pada printer (push print job). Ketiga background tersebut yang membentuk sistem otomasi pada layanan cetak.

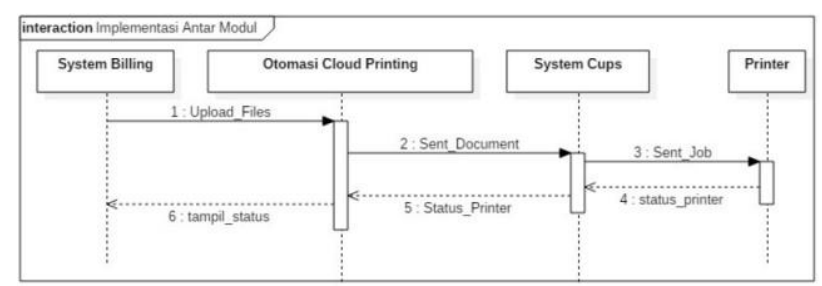

Gambar 2. Interaksi antara dua modul, sistem CUPS dan Printer

\subsubsection{Background Proses Pull Printer Status (PPS)}

Table 2 menunjukan tiga jenis status printer yang diperiksa beserta nilainya. Jenis status Power dan status Printer adalah status respon printer yang diberikan oleh CUPS, sedangkan status Antrian adalah status tambahan yang diubah secara manual oleh administrator melalui halaman manajemen printer. Sebagian besar printer yang digunakan di masyarakat adalah printer yang cartridge tintanya telah dimodifikasi, sehingga printer tidak akan memberikan sinyal tinta habis. Pada kasus jenis printer laser jenis modifikasi yang dilakukan adalah dengan mengisi ulang toner. Dengan merubah status antrian ke Disabled, sebuah printer yang sedang melakukan proses cetak tetap akan menyelesaikan proses cetak yang sedang dikerjakan akan tetapi print job selanjutnya tidak akan diberikan ke printer tersebut. 
Tabel 2 Jenis status printer

\begin{tabular}{|l|c|c|}
\hline Jenis Status & \multicolumn{2}{|c|}{ Nilai } \\
\hline Power & Connected & Disconnected \\
\hline Printer & Idle & Busy \\
\hline Antrian & Enabled & Disabled \\
\hline
\end{tabular}

Tabel 3 Nilai pada jenis status printer

\begin{tabular}{|c|c|}
\hline Kondisi & Status Printer \\
\hline Standby & Idle \\
\hline Cetak Dokumen & Busy \\
\hline Kertas Habis & Busy \\
\hline Kertas Macet & Busy \\
\hline
\end{tabular}

Untuk mendapatkan nilai status printer yang diberikan oleh CUPS, dilakukan percobaan dengan 4 kondisi. Keempat kondisi tersebut dilakukan dalam status Power Connected. Nilai yang didapat dari percobaan tersebut diberikan pada tabel 3. CUPS hanya memberikan dua status untuk printer, yaitu Idle dan Busy. Status Idle menunjukan bahwa printer siap menerima sebuah print job. Ketika printer sedang melakukan proses cetak, CUPS memberikan status Busy. Berdasarkan halaman resmi CUPS [10], CUPS dapat memberikan status out of paper dan media jam pada kondisi kertas habis dan kertas macet. Pada percobaan yang dilakukan, CUPS hanya memberikan respon status Busy untuk kedua kondisi tersebut. Percobaan ini dilakukan menggunakan komputer dengan spesifikasi prosesor Core I5 dan RAM sebesar 4Gb. Sistem operasi yang digunakan adalah Ubuntu 16.04 dengan CUPS versi 2.0.

Dari 6 nilai status dari tabel 2 diturunkan menjadi 4 nilai status dengan keterangan masing-masing status

seperti yang terlihat pada tabel 4 . Keempat status tersebut adalah status yang diberikan oleh SCP. Alur kerja PPS seperti yang digambarkan oleh gambar 3. Status Busy memiliki dua kondisi, detail penjelasan ada pada tabel 3. Sebuah printer yang memiliki status Busy dalam kurun waktu yang lama berpotensi sedang mengalami masalah. Jika terjadi masalah sebuah printer, hanya akan

berdampak pada satu print job saja. Print job yang terdampak adalah print job yang sedang diproses oleh

printer tersebut. Hal ini dapat dilakukan karena SCP memiliki sistem antrian sendiri. SCP hanya mengirim satu print job ke satu printer dengan status idle.

Tabel 4 Status Printer di SCP

\begin{tabular}{|c|c|}
\hline Status printer di SCP & Kondisi \\
\hline Disconnected & Printer dalam kondisi mati \\
\hline Maintenance & Perbaikan printer oleh admin \\
\hline
\end{tabular}

\begin{tabular}{|c|c|}
\hline Idle & Siap menerima Print Job \\
\hline Busy & $\begin{array}{c}\text { Proses Cetak / terjadi } \\
\text { masalah }\end{array}$ \\
\hline
\end{tabular}

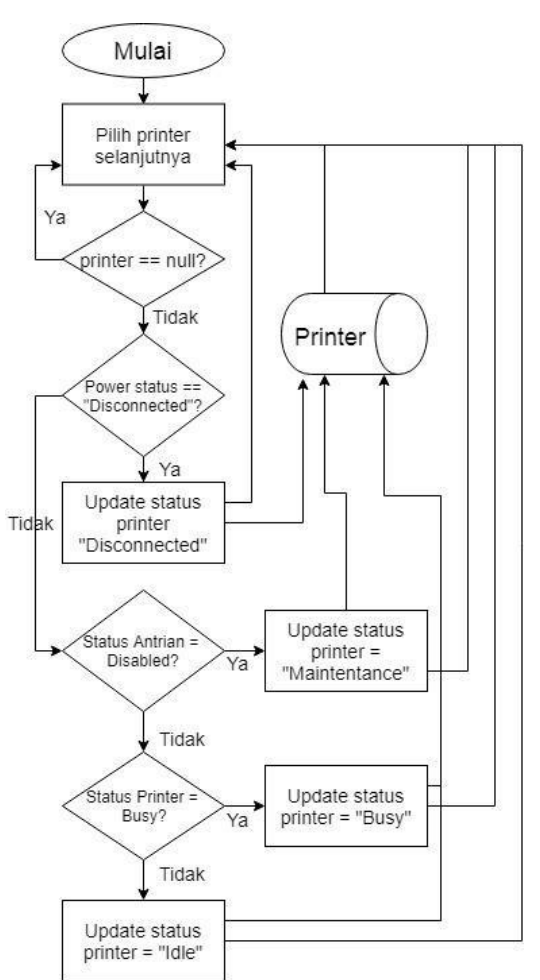

Gambar 3. Flowchart pull printer status

\subsubsection{Background Proses Push Print Job (PPJ)}

Sebuah print job memiliki 4 status seperti yang terlihat pada tabel 5. Alur kerja PPJ dapat dijelaskan melalui gambar 4. Setiap print job memiliki spesifikasi cetak, sebagai contoh sebuah print job memiliki spesifikasi cetak hitam putih pada kertas A4. PPJS harus mampu mengirimkan sebuah print job kepada printer dengan spesifikasi yang sesuai dan proses pencocokan spesifikasi cetak dan printer terus dilakukan selama terdapat printer dengan status idle.

Sebagai contoh sebuah studi kasus yang diberikan pada tabel 6 , terdapat 3 printer dan 4 print job dengan spesifikasi yang tertera pada tabel. PJ_1 akan dicetak oleh Pr_3, PJ_2 akan dicetak oleh Pr_2 dan PJ_4 akan dicetak oleh Pr_1. Pengerjaan PJ_3 dilewati dan PJ_4 dikerjakan terlebih dahulu karena printer yang memiliki spesifikasi yang sesuai untuk PJ_3 adalah $\mathrm{Pr}$ 2, sedangkan printer yang idle pada saat ini adalah $\operatorname{Pr} 1$. Karena masih terdapat sebuah printer dengan status idle, PPJ melakukan proses pencocokan spesifikasi printer pada print job selanjutnya. Hal tersebut dilakukan untuk mendapatkan performa layanan cetak yang tinggi.

Tabel 5 Status Print Job

Program Studi Teknik Informatika

Universitas Prima Indonesia (UNPRI) Medan 


\begin{tabular}{|c|c|}
\hline Status Print Job & Keterangan \\
\hline 0 & Belum dicetak \\
\hline 1 & Sedang dicetak \\
\hline 2 & Sudah dicetak \\
\hline 3 & Batal cetak \\
\hline
\end{tabular}

Tabel 6 Studi kasus

\begin{tabular}{|l|l|}
\hline Printer & \multicolumn{1}{|c|}{ Spesifikasi } \\
\hline Pr_1 & A4, Hitam Putih \\
\hline Pr_2 & F4, Warna \\
\hline Pr_3 & A4, Warna \\
\hline & \\
\hline
\end{tabular}

\begin{tabular}{|c|l|}
\hline $\begin{array}{c}\text { Print } \\
\text { Job }\end{array}$ & \multicolumn{1}{|c|}{ Spesifikasi } \\
\hline PJ_1 & A4, Warna \\
\hline PJ_2 & F4, Hitam Putih \\
\hline PJ_3 & F4, Warna \\
\hline PJ_4 & A4, Hitm Putih \\
\hline
\end{tabular}

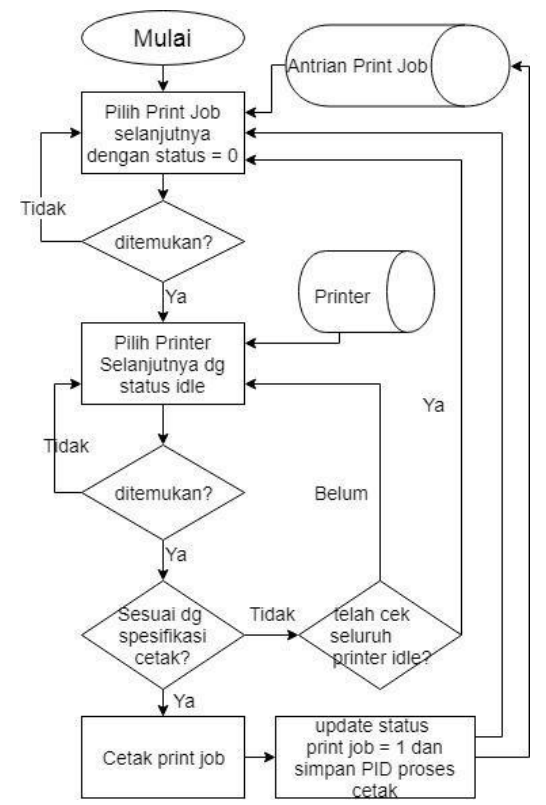

Gambar 4. Flowchart push print job

\subsubsection{Background Proses Pull Print Job Status (PPJS)}

Proses background yang terakhir adalah pull print job status (PPJS). PPJS berfungsi untuk memeriksa status seluruh print job yang memiliki status "sedang dicetak". Alur kerja PPJS dapat dijelaskan melalui gambar 5.

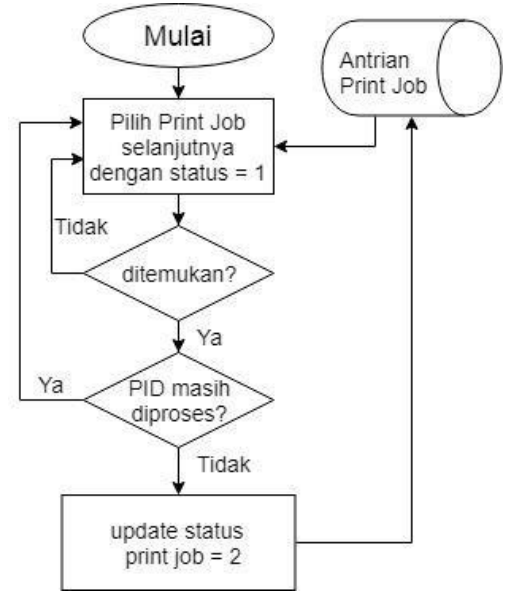

Gambar 5. Flowchart pull print job status

\subsection{Tampilan SCP}

Seperti yang telah dijelaskan pada sub bab sebelumnya, bahwa fokus pada penulisan ini adalah pengembangan sistem otomasi cetak pada SCP. Halaman yang ditampilkan pada sub bab ini adalah halaman terkait proses cetak dokumen.

\subsubsection{Form unggah file}

Halaman ini diakses oleh pengguna layanan untuk mengunggah file yang akan dicetak.

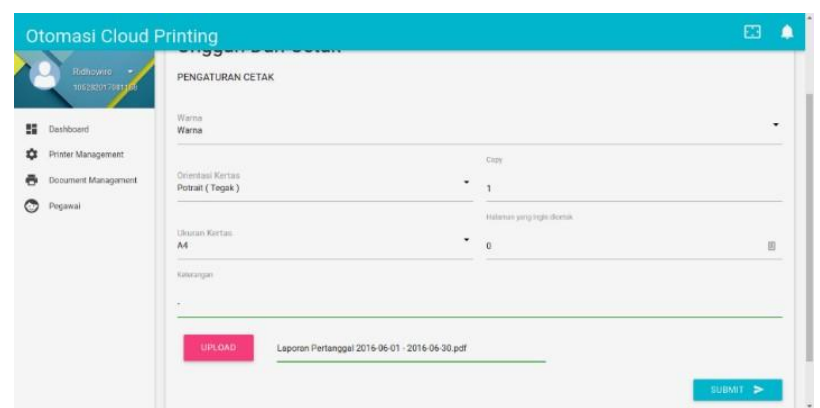

Gambar 6. Form unggah file untuk dicetak

\subsubsection{Halaman status file yang akan dicetak}

Pengguna dapat memantau status cetak dari file yang di unggah melalui halaman yang ditunjukan gambar 7 .

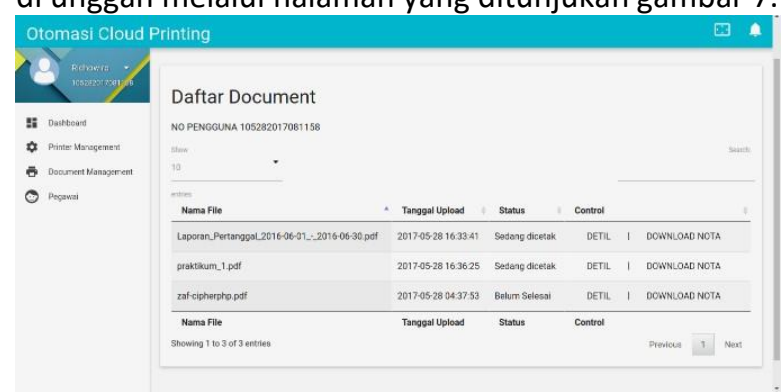

Gambar 7. Status file 


\subsubsection{Halaman daftar printer}

Daftar printer yang terpasang beserta statusnya ditampilkan pada halaman ini. Halaman ini adalah salah satu bagian dari layanan manajemen printer yang hanya dapat diakses oleh akun penyedia jasa.

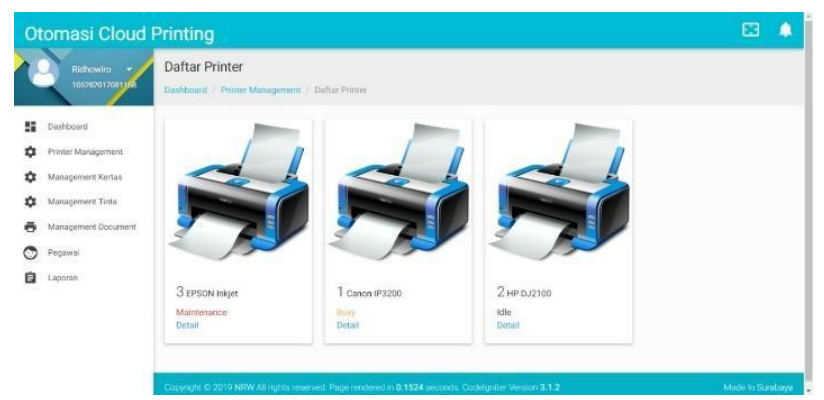

Gambar 8. Daftar printer pada SCP

\subsubsection{Halaman informasi detail printer}

Halaman yang menampilkan informasi detail dari sebuah printer yang terpasang pada SCP dan dapat digunakan untuk melayani layanan cetak. Halaman ini hanya dapat diakses oleh pengguna dengan hak akses penyedia jasa.

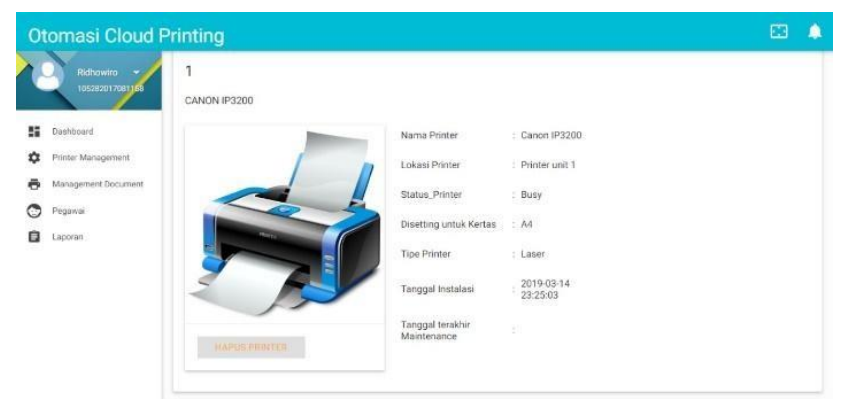

Gambar 9. Detail Printer

\section{Kesimpulan}

1. Survey yang dilakukan pada 100 mahasiswa Fakultas Vokasi Universitas Airlangga menunjukan bahwa mahasiswa mengharapkan adanya layanan cetak didalam fakultas.

2. Survey dengan menggunakan model Kano untuk menganalisa kebutuhan fitur pada layanan cetak menunjukan bahwa layanan cetak yang ditawarkan secara online dan pengguna tetap dapat beraktifitas selama menunggu dokumen tercetak dapat memberikan dampak yang positif pada SCP.

3. Untuk membentuk sistem cetak yang otonom diperlukan tiga background proses; pull printer status, pull printer job status dan push printer job.

4. CUPS digunakan dalam implementasi otomasi sistem cetak.
5. CUPS hanya memberikan dua status printer; Idle dan Busy.

6. CUPS juga memberikan status printer Busy untuk printer yang sedang mengalami masalah. SCP masih belum mampu mengidentifikasi apakah sebuah printer sedang melakukan proses cetak atau sedang mengalami masalah pada status ini.

7. Lamanya kurun waktu status Busy pada sebuah printer dapat digunakan untuk mengidentifikasi bahwa printer tersebut sedang mengalami masalah. Sebuah proses yang melakukan fungsi ini perlu untuk dikembangkan.

8. Hanya satu print job yang akan terdampak jika terjadi masalah pada sebuah printer.

9. Fokus pada penulisan ini adalah pengembangan otomasi layanan cetak pada SCP. Secara keseluruhan, SCP terdiri dari beberapa komponen yang detailnya tidak dideskripsikan pada tulisan ini.

\section{Referensi}

[1] Q. Xu, X. J. Yang, R. J. Jiao and A. Opperud, "An Analytic Kano Model For Customer Need Analysis," Elsevier, vol. 87, p. 110, 2009.

[2] V. Wu, H. Singh, L. Ormond and M. Kuo, "Online print with driverless web print server". US Patent US 2004/0130744.

[3] J. D. Levine, B. G. Gombert and J. L. Mayer, "Centralized print server for interfacing one or more network clients with a plurality of printing devices". US Patent 5974234, 1999.

[4] Tanaka, "Web-based print server and client". US Patent 7303345, 2007.

[5] Papercut Software Internationall, 2016. [Online]. Available: https://www.papercut.com/.

[6] Thinprint GMBH, 2016. [Online]. Available: https://www.thinprint.com/.

[7] A. M. Elhanafi, I. Lubis, D. Irwan and A. Muhazir, "Simulasi Implementasi Load Balancing PCC Menggunakan Simulator GnS3," Jurnal Teknik Informatika Komputer, 2018.

[8] A. Hussain, E. O. Mkpojiogu and F. M. Kamal, "Eliciting User Satisfying Requirements for an eHealth Awareness System Using Kano Model," in 14th International Conference on Applied Computer and Applied Computational Science, Kuala Lumpur, 2015.

[9] F. Pauliot, "Theoretical Issues of Kano's Methods on Kano's Methods for Understanding Customerdefined Quality," Center for Quality of Management Journal, 1993. 
[10] Apple Inc., "CUPS.org," CUPS, [Online]. Available: https://www.cups.org/documentation.html. [Accessed 2 Maret 2019].

[11] N. Kano, "Attractive Quality and Must-be Quality," in Nippon QC Gakka: 12th Annual Meeting, 1984.

[12] Apple Inc., "CUPS.org," CUPS, [Online]. Available: https://www.cups.org/documentation.html. [Accessed 2019]. 